\title{
Accidental Closantel Poisoning in Sheep in the State of Rio Grande do Sul - Brazil
}

\author{
Camila Blanco Pohl, Marina Paula Lorenzett, Bianca Santana de Cecco, \\ Luan Cleber Henker, Welden Panziera \& David Driemeier
}

\begin{abstract}
Background: Verminosis is one of the major health problems in sheep flocks, and is one of the main causes of death in sheep worldwide. Closantel is an antiparasitic drug commonly used in sheep; however, its safety margin is narrow, and this drug may induce intoxication in animals submitted to high doses. Lesions occur mainly in the eyes, and are characterized by edema and compression of the optic nerve, retinopathy, and severe degeneration of ganglia cells. Clinical signs are pupil dilation, which often lead to permanent blindness. This work aims to report an outbreak of sheep mortality due to closantel intoxication, associated with inadequate anthelmintic administration practices.

Case: An on-site visit was conducted to a sheep farm, located in the municipality of Osório, Rio Grande do Sul (RS) - Brazil, in which high mortality was reported. The flock consisted of approximately 300 Texel sheep, managed in an extensive grazing system. Lambs and adult animals were affected. According to the information provided by the farm owner, many animals presented clinical signs of haemonchosis, and a closantel dose of $20 \mathrm{mg} /$ lamb was administered in all sheep, regardless of body weight. Lambs weighted on average $13 \mathrm{~kg}$. After closantel administration, several sheep presented neurologic signs and died. At the clinical examination, sheep presented pallor of ocular mucous membranes, as well as submandibular edema. Also, 20 lambs showed signs of blindness, disorientation and bumping into objects, as well as hypothermia and lack of response to the menace reflex. Three 30 to 45 -day-old male lambs that died spontaneously were submitted for necropsy. Grossly, only mild ascites was noted. Histopathological examination of the retina showed degeneration and fragmentation of photoreceptor layer as well as depletion of the inner nuclear layer, associated with pyknosis and karyorrhexis. There was also a reduction in the number of ganglia cells in the ganglion cell layer and atrophy and vacuolization in the outer plexiform layer. In the optic nerve, multifocal mild to moderate vacuolization was observed. Diffuse perineural and perivascular edema were observed in the brain, predominantly in the grey matter. In the encephalon of one of the lambs, multifocal vacuolization was observed, which was also evidenced at the junction of the white and gray matter of the telencephalon, and in the white matter of the cerebellum. In the trigeminal ganglia, moderate multifocal vacuolization was noted in the perikaryon of neurons. Furthermore, the spinal cord had moderate multifocal vacuolization at the junction of white and gray matter.

Discussion: the diagnosis of closantel intoxication in sheep was based on the clinical history and histopathological findings. The association of these data is crucial to suspect and confirm the diagnosis of this type of intoxication. Closantel is an anthelmintic drug widely used in sheep, and in correct doses may be very effective, but when used in doses higher than recommended may lead to irreversible lesions. The optical damage is derived from edema which leads to degeneration of ganglia cells and injury to the optic nerve. Another proposed mechanism is related to optic nerve compression causing rupture and edema of retinal structures. Lesions tend to be dose related, and poisoning usually occurs when treating groups of animals based on the weight of the heaviest animal. Clinical signs of blindness and pupil dilatation are usually seen. There is no effective treatment for reversion of this condition; therefore, prevention based on correct calculation of anthelmintic dose is pivotal. The epidemiological examination, clinical signs and anatomopathological examination were extremely important to make the final diagnosis of this intoxication.
\end{abstract}

Keywords: ocular lesions, toxicology, anthelmintic, blindness. 


\section{INTRODUCTION}

Verminosis is one of the major sanitary proble$\mathrm{ms}$ in sheep flocks, and is one of the main causes of death in sheep worldwide [3]. The control of gastrointestinal parasites is performed through the administration of anthelmintic drugs, which may be indispensable in tropical and humid areas, in which these agents tend to be more prevalent [5]. Anthelmintic drugs such as closantel, which is a halogenated salicylanilide, is used extensively to control Haemonchus spp. and Fasciola spp. in sheep [2-4,15,21].

Although closantel has a high anthelmintic efficacy for sheep in some regions, occasionally we can observe intoxication cases $[10,16]$. Poisoning may occur when treating groups of animals based on the weight of the heaviest animal, or based on the average weight, which may lead to overdose in lighter animals. When the dose is two to five times higher than recommended, clinical signs may be observed [3]. The intoxication causes permanent blindness, with no chance of effective treatment [16]. This case report aimed to describe an outbreak of closantel intoxication in a sheep flock, and describe the epidemiological and histological features of the lesions caused by this intoxication.

\section{CASE}

An on-site visit was conducted to a sheep farm, located in the municipality of Osório, state of Rio Grande do Sul (RS), in which high mortality was reported. The flock consisted of approximately 300 Texel sheep, managed in an extensive grazing system. Lambs and adult animals were affected. According to the owner's report, the lambs were routinely dewormed with ivermectin and closantel. A dose of closantel of $20 \mathrm{mg} /$ lamb was used, regardless of the individual body weight, and the lambs had an average weight of $13 \mathrm{~kg}$. The owner reported that, 40 lambs in total died in the referred lambing season, with the majority presenting mucosal pallor and submandibular edema. A new application of closantel at the same dose above mentioned was administered, and in about ten days ten lambs showed signs of blindness, disorientation, dying in a short period of time.

At the clinical evaluation, sheep presented submandibular and facial edema, ocular mucosa pallor. Also, approximately 20 lambs showed signs of blindness, disorientation and bumping into objects,

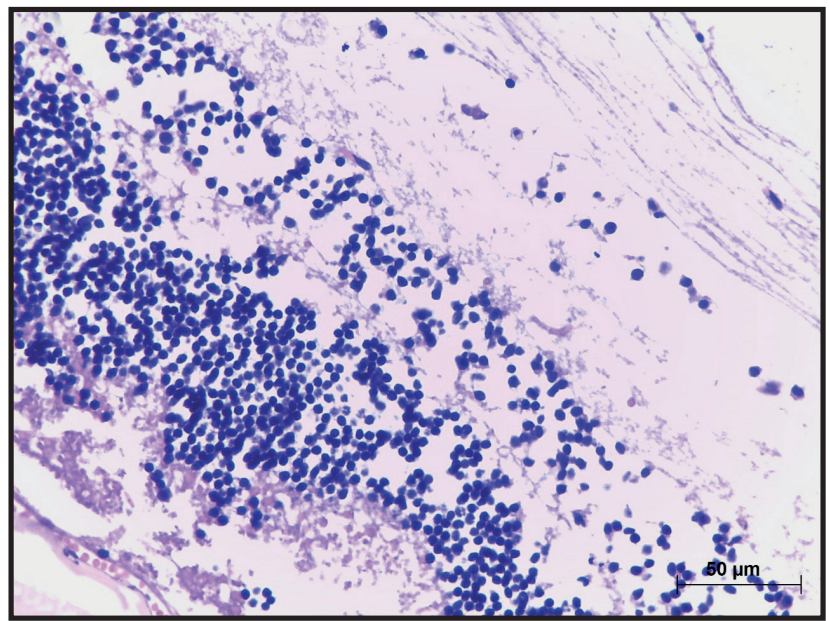

Figure 1. Retina of an affected lamb, there is degeneration and fragmentation of the photoreceptor layer as well as depletion of the nuclear layers, associated with pyknosis and karyorrhexis. A reduction in the number of ganglia cells in the ganglion cell layer, and atrophy and vacuolization are observed in the outer plexiform layer.

as well as hypothermia and lack of response to the menace reflex. Ewes were clinically evaluated and showed signs of submandibular edema and pallor of ocular mucosa; however, none of the ewes presented neurologic or ocular signs. Three male lambs, with age ranging from 30 to 45 days, which died spontaneously, were submitted for necropsy. At necropsy the animals presented good body condition, and normal coloration of ocular mucosae. No significant alterations were observed in other organs.

Histopathological examination revealed similar lesions in the three lambs. The main lesions were found in the eyes (Figure 1), and included degeneration and fragmentation of the photoreceptor layer as well as depletion of the inner nuclear layer, associated with pyknosis and karyorrhexis. There was also a reduction in the number of ganglia cells in the ganglion cell layer and atrophy and vacuolization in the outer plexiform layer. In the optic nerve, multifocal mild to moderate vacuolization was observed (Figure 2). Diffuse perineural and perivascular edema were noticed in the brain, predominantly in gray matter. In the encephalon of one of the lambs, multifocal vacuolization was observed, which was also evidenced at the junction of the white and gray matter of the telencephalon, and in the white matter of the cerebellum. In the trigeminal ganglia, moderate multifocal vacuolization was noted in the perikaryon of neurons (Figure 3). Furthermore, the spinal cord had moderate multifocal vacuolization at the junction of white and gray matter. 


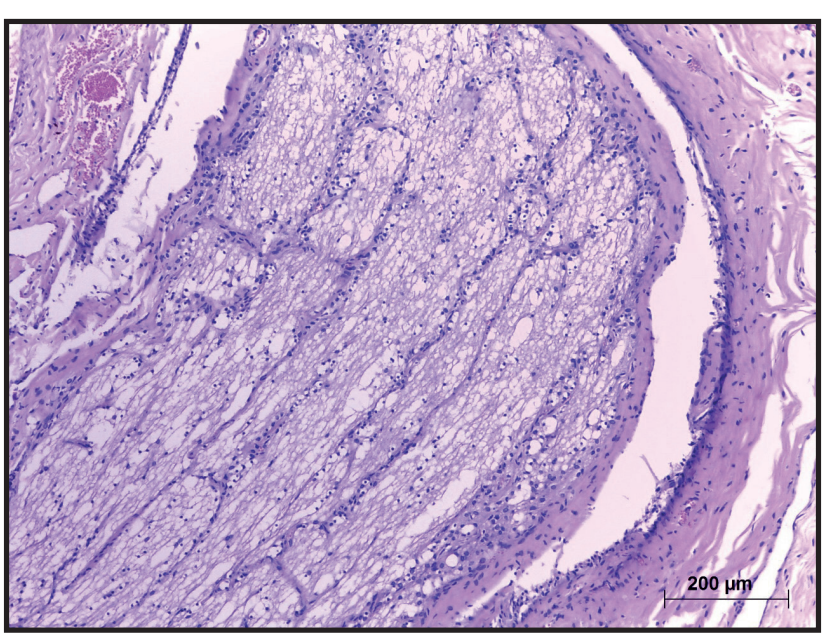

Figure 2. The optic nerve of an affected lamb presenting multifocal vacuolization.

\section{DISCUSSION}

Sheep production has been growing steadily in the last years in Brazil, and this economic activity has become important in several Brazilian states, mainly in the South and in the Northeast regions of Brazil [19]. However, the rise in sheep production is accompanied by increased sanitary problems, including gastroenteric verminosis, which lead to significant economic losses associated weight loss, reduced wool quality and increased mortality rates [8]. Among domestic animals, sheep are the most affected by endoparasites, and young animals tend to be more susceptible $[1,4]$. Gastroenteric verminosis represents the main cause of economic losses in sheep flocks and may lead to the death of affected animals $[1,9,18]$. In the present study, young animals were more affected by verminosis, which reinforces literature data.

Closantel is an anthelmintic drug derived from salycilanilides, used to control trematodes, nematodes and cestodes, which is frequently employed in the control of gastroenteric parasites in ruminants. In 2002, the first description of closantel resistance has been reported, and currently different levels of anthelmintic resistance for this drug have been documented, which may lead to reduced drug efficiency $[3,4,9,14,16]$. This anthelmintic drug acts decreasing the parasite's mitochondrial reactions related to electron transport and ATP synthesis [3], consequently preventing oxidative phosphorylation and energy production. This ultimately leads to the death of the parasite due to spastic paralysis associated with increased concentrations of calcium ions in muscle cells [3].

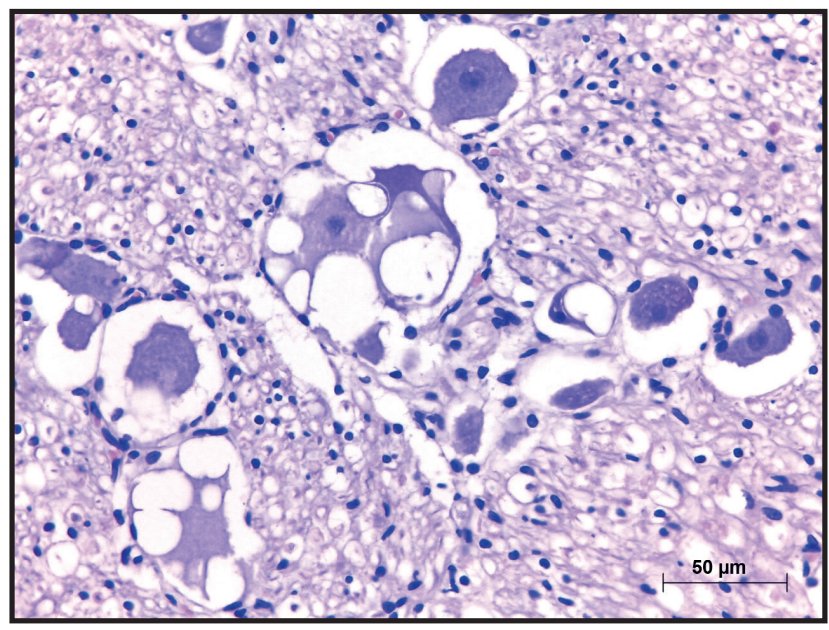

Figure 3. Trigeminal ganglion of an affected lamb presenting vacuolization.

The mechanism of closantel poisoning remains poorly understood in sheep; nevertheless, some previous studies suggest that ocular lesions are associated with optic neuropathy following retinal edema $[10,11,17]$. Edema leads to the degeneration of ganglia cells, reflecting in the toxic effect on neurons. Moreover, axonal lesions in the optic nerve may occur $[17,19]$. Other mechanisms which may be involved in lesion development include optic nerve compression within the bone structures of the optic canal and the rupture of cells and compacted cell membrane layers, these are associated with retinopathy, myelin edema and white matter vacuolation $[11,16]$.

Closantel poisoning may occur in sheep flocks treated with doses above the recommended [3]. Similarly, to the present case, certain management practices, including the calculation of the anthelmintic dose based on the body weight of the heaviest lamb, are frequently associated with cases of intoxication. In this case, the worker responsible for deworming estimated the average body weight of lambs as $20 \mathrm{~kg}$; however, average body weight of the group was in fact approximately $13 \mathrm{~kg}$. In this case, a dose of $20 \mathrm{mg}$ was administered to each lamb, while the anthelmintic drug label recommendation was $1 \mathrm{mg} / \mathrm{kg}$. Therefore, it is possible to infer that some lambs received nearly the double of the recommended dose. When administered doses are two to five times higher than the recommended, clinical sings characterized by blindness and pupil dilation, as well as circling movements are observed, similarly to the present report $[3,6,16]$. Blindness occurs within two days to two weeks after closantel administration [3]. The interval between the overdose 
and the onset of clinical signs is directly linked to the level of overdose [11].

Generally, no macroscopic lesions are observed, except narrowing of the intracanalicular segment of the optic nerve. Histological lesions are characterized by retinal degeneration, characterized by degeneration of cells from the outer nuclear layer and loss of ganglion neurons $[6,10,16]$. Optic nerve lesions are characterized by intramyelinic edema $[6,10,16]$. As a result of compression, there is necrosis, foamy macrophage infiltrate and intracanalicular nerve fibrosis, and loss of ganglion cells. Preferably perivascular and perineural intramyelinic edema is observed quite frequently in these cases $[6,10,16]$.

Plant intoxications should be included as a differential diagnosis in the present case [20]. Retinal degeneration and atrophy, without optic nerve alterations, have been reported in cases of Pteridium arachnoideum (bracken fern) poisoning; however, this pathological presentation has never been recorded in Brazil [7,12,21]. In the present study, no plants associated with such condition were observed in the grazing area where sheep were kept.

Closantel may present low efficacy against helminths in some areas, which may be associated with inadequate management and excessive use of antiparasitic drugs, as well as rapid rotation of anthelmintic drugs and the introduction of infected animals to the flock [13]. Therefore, prevention is crucial, and ideally, closantel doses should be correctly calculated before administration [16]. Besides that, proper animal identification is extremely important, as well as separating animals into categories based on body weight in order to avoid drug overdose.

The present findings reaffirm that closantel poisoning is an important disease affecting sheep, which may lead to irreversible ocular damage; therefore, extreme care regarding the administration of this anthelmintic drug is necessary, in order to avoid economic losses.

Declaration of interest. The authors report no conflicts of interest. The authors alone are responsible for the content and writing of paper.

\section{REFERENCES}

1 Amarante A.F.T. \& Sales R.O. 2007. Controle de Endoparasitoses dos ovinos: Uma Revisão. Revista Brasileira de Higiene e Sanidade Animal. 1(2): 14-36.

2 Amarante A.F.T. 2014. Classe Nematoda. In: Os Parasitas de Ovinos [online]. São Paulo: Editora UNESP, pp.13-97.

3 Andrade S.F. \& Santarém V.A. 2002. Endoparasitida e ectoparasitida. In: Manual de Terapêutica Veterinária. 2.ed. São Paulo: Roca, pp.469-470.

4 Borges C.C.L. 2003. Atividade in vitro de anti-helmínticos sobre larvas infectantes de nematódeos gastrintestinais de caprinos, utilizando a técnica de coprocultura quantitativa (Ueno, 1995). Parasitologia Latinoamericana. 58: 142-147.

5 Charles T.P. 1989. Seasonal prevalence of nematodes of goats in Pernambuco State, Brazil. Veterinary Parasitology. 30: 335-343.

6 Ecco R., Gava A. \& Graça D.L. 1999. Intoxicação por closantel em caprinos: relato de caso. In: Anais do 9o Encontro Nacional de Patologia Veterinária (Belo Horizonte, Brasil). p.91.

7 Ecco R., Barros C.S.L. \& Graça D.L. 2008. Alterações oftálmicas associadas à intoxicação experimental por closantel em caprinos. Arquivo Brasileiro de Medicina Veterinária e Zootecnia. 60: 42-50.

8 Echevarria F.A.M., Pinheiro A.C. \& Corrêa M.B.C. 1988. Alternativas para o controle da verminose ovina no Rio Grande do Sul. Comunicado Técnico do Centro Nacional de Pesquisa de Ovinos da EMBRAPA. 8: 6p.

9 Furlan F.H., Lucioli J., Borelli V., Fonteque J.H., Stolf L. Traverso S.D. \& Gava A. 2009. Intoxicação por closantel em ovinos e caprinos no Estado de Santa Catarina. Pesquisa Veterinária Brasileira. 29(1): 89-93.

10 Gill P.A., Cook R.W. \& Boulton J.G. 1999. Optic neuropathy in closantel toxicosis of sheep and goats. Australian Veterinary Journal. 77: 259-261.

11 Hannon F.P., Ellis K.A., Guevar J., Marchesi F., Geraghty T. \& Geleach J.D. 2014. Closantel toxicity in a pregnant ewe at mid gestation: the pathological evaluation of the ewe and lamb nine months later. Veterinary Record Case Reports. 2(1): e000113.

12 Hirono I., Ito M., Yagyu S., Haga M., Wakamatsu K., Kishikawa T., Nishikawa O., Yamada K., Ojika M. \& Kigoshi H. 1993. Reproduction of progressive retinal degeneration (bright blindness) in sheep by administration of Ptaquiloside contained in bracken. Journal of Veterinary Medical Science. 55: 973-983. 
13 Molento M.B. 2005. Avanços no diagnóstico e controle das helmintoses em caprinos. In: I Simpósio Paulista de Caprinocultura (SIMPAC). Jaboticabal: Multipress, pp.101-110.

14 Ramos C.I., Bellato V., Ávilla V.S., Coutinho G.C. \& Souza A.P. 2002. Resistência de parasitos gastrointestinais de ovinos a alguns anti-helmínticos no Estado de Santa Catarina, Brasil. Ciência Rural. 32(3): 473-477.

15 Ribeiro L.A.O. 1988. Atualidades na profilaxia das enfermidades infecciosas dos ovinos. In: Anais do lo Simpósio Paulista de Ovinocultura (Botucatu, Brasil). Campinas: Fundação Cargill, p.143.

16 Riet-Correa F. 2007. Intoxicação por closantel. In: Schild A.L., Lemos R.A.A. \& Borges J.R. (Eds). Doenças de Ruminantes e Equídeos. Santa Maria: Pallotti, pp.60-62.

17 Rivero R., Matto C., Soares M.P. \& Adrien M.D.L. 2015. Accidental and experimental Closantel intoxication in Uruguayan sheep. Pesquisa Veterinária Brasileira. 35(7): 599-604.

18 Urquhart G.M., Armour J., Duncan J.L., Dunn A.M. \& Jennings F.W. 1998. Parasitologia Veterinária. Rio de Janeiro: Guanabara Koogan, 273p.

19 Van der Lugt J.J. \& Venter I. 2007. Myelin vacuolation, optic neuropathy and retinal degeneration after closantel overdosage in sheep and in a goat. Journal of Comparative Pathology. 136(2-3): 87-95.

20 Whittington R.J., Searson J.E. \& Whittaker S.J. 1988. Blindness in goats following ingestion of Stypandra glauca. Australian Veterinary Journal. 65(6): 176-181.

21 Yamamoto S.M., Macedo F.A.F., Zundt A.M., Sakaguti E.S., Rocha G.B.L., Regaçoni K.C.T. \& Macedo R.M.G. 2005. Fontes de óleo vegetal na dieta de cordeiros em confinamento. Revista Brasileira de Zootecnia. 34(2): 703-710. 